\title{
Visayan Philosophy of Labor: A Reflection from the Notion of Kahimtang and John Paul I's Philosophy
}

\author{
Arian Acampado ${ }^{*}$, and Glenn G. Pajares ${ }^{2}$ \\ 1 Visayas State University - Tolosa, Leyte, Philippines, https://orcid.org/0000-0003-4000-9643 \\ 2 University of San Jose-Recoletos, Cebu City, Philippines, https://orcid.org/0000-0003-1151-2995 \\ *Email Correspondence: arian.acampado@vsu.edu.ph
}

\begin{abstract}
This paper highlights John Paul II's (JPII) Philosophy of Labor and points out the need to have a Visayan philosophy of labor. Moreover, this proposes to view and analyze the Visayan philosophy of labor within the context of the Visayan notion of kahimtang. The researchers believe that the word kahimtang can be viewed as a combination of three words ka, himu and butang, in which himu connotes a concept of work. Furthermore, within the compatibilist minds of the Visayan, himu (labor) plays a significant role to redirect one's kahimtang. Work (labor), for the Visayan, is an essential expression of freedom which has a similar expression to JPII's Philosophy of Labor.
\end{abstract}

Keywords: Kahimtang, Labor, John Paul II, Filipino Philosophy, Visayan Philosophy

\subsection{Introduction}

Filipino philosophy, though gaining a significant number of supporters, has its share of critics. Two of its criticisms are the lack of method and a western tradition within an eastern setting (Pada, 2014; Gripaldo, 2007). Nonetheless, Filipino philosophy thrives as outlined by Mercado (2016), in his reflections on Filipino philosophy's status, and Demeterio (2014), in his work on assessing some discourses on Filipino philosophy, where he claimed that the question "Is there a Filipino philosophy?" is obsolete. As Filipino philosophy continues to growand develop, part of it must be the discussion on Visayan perspectives that will surely make the philosophical arguments of philosophy more exciting and livelier. However, looking into reality, though there are several Visayans who are considered scholars in philosophy, only a few seriously tackle philosophy with a Visayan theme and concepts. Hence, this paper aims to work on that aspect. Reflecting on JPII's philosophy of labor, the researchers have seen the need for an alternate and contextualized understanding of labor. To do this task, the researchers aim to examine the Visayan notion of Kahimtang with the hope of unfolding a rich Visayan philosophy of labor. However, one might ask, "Why chose John Paul II among other philosophers who discussed about labor?" The researchers revisit the Philosophy of John Paul II for two reasons: first, he was a great thinker who has just had his birth's centennial anniversary; second, he is considered as one of the greatest leaders of the Catholic Church in which many Visayan people belong to. These people celebrate this year the quincentennial anniversary of Christianity in the Philippines. One of John Paul Il's famous encyclicals 
is entitled "Laborem Exercens," where he detailed his thoughts on labor and work, which can be very enriching to the Visayan idea of labor. He even mentioned that work needs constant renewed attention because it always offers new questions and threats (LE 1). The researcher revisits this work to understand JPII's Philosophy of labor then reflect and compare it with the Visayan thoughts on labor. By doing this, the researchers hope to find fresh perspectives about the discussion of Labor (work) as a whole.

On the one hand, there are very few existing works on Visayan philosophy. To mention some, Fernandez (2017) talks about the peace concepts of Visayan folks, Velez (2018) talks about the Philosophy of Nayanaya- a philosophy of survival which includes the Visayan concept, the work of Acampado and Fernandez (2019) on kahimtang and space, the article of Ocay (2015) on philosophy of work of the elderly people in Sitio Pinayun-an, a remote village in Barangay Bato, Mabinay, Negros Oriental and some concepts included in the works of Mercado (1974) on the "Elements of Filipino Philosophy." Though there are several works about the Visayan people, these works focused more on the Visayan anthropological side. For this reason, the writer wants to enrich more the philosophical discussion of the Visayan by focusing on their idea of labor or work as understood from the framework of kahimtang. Meanwhile, several philosophic works exist that tackle labor in general and the thought of John Paul II, in particular. Some of these works talk about John Paul Il's idea on the priority of labor over capital (Russo and Corbin, 1999; Baum, 1982). Others compared the philosophy of John Paul II with other philosophers. Acaali (1997) researched the Philosophy of John Paul II on labor and compared it with Julius Nyerere's philosophy to enrich the discussion and perspective of labor. He looked into man's idea as the subject of work by JPII and Nyerere's view of the communal notion of work. Wisman (1998) made a critical study of John Paul Il's stance on work and calls it the most progressive stance on socio-economic issues. Clark (2007) also exposed John Paul II and Amartya Sen's position and argued on the integral perspective of human rights amidst conflicts. Herbert (2013) made a study on Josef Pieper and John Paul II's philosophy, the latter claiming that man's dignity consists of being free from work while the latter claiming that work adds to the dignity of man. Matheny (2014) traced the decline of labor unions from $37 \%$ in 1946 to $6.6 \%$ in 2009 . He used the encyclicals of Benedict XVI and John Paul II in discussing the significance of the associations.

This article focuses on the exposition of the Visayan understanding of labor from the notion of kahimtang using the lens of John Paul II's philosophy of work found in Laborem Exercens. Work is an essential part of existence where it can be well appreciated or exploited. It is tied within the very core of human nature. Understanding the Visayan notion of labor may contribute to the enlightened way humans looked at labor, and it may produce a renewed commitment to work. Furthermore, articulating the Visayan idea of labor will lead to a deeper appreciation of work that might lead to a meaningful existence, especially to the Visayan, whose context this whole quest is based. A profound understanding of reality is the aim of every person searching for the truth. This commitment to a deeper understanding of labor will hopefully lead to a better perspective and policy. In this way, the researchers contribute to Filipino philosophy and the building of Visayan philosophy in particular. John Paul II's philosophy on labor has been compared and contrasted to different philosophers. The writer sees the positive effect of his philosophy on the Visayan to enrich their awareness of the value of work and the human person. While kahimtang is a Visayan concept, this might be an experience relatively applicable to all. 


\subsection{Methodology}

This research endeavor is a philosophical exposition and analysis of JPII's philosophy of labor and points out the need for an indigenous philosophy that reflects the Visayan context. With the help of existing literature, the researchers philosophically analyze the Visayan notion of kahimtang and argue for a Visayan philosophy of labor that is anchored on the nuances of kahimtang.

\section{Operational Definition of the Visayan Terms Used}

Kahimtang is a term used by Cebuano and Winaray language which refers to the whole condition and status of a person. It is used in this research to mean a God-given State of Beinghuman.

Buhat is a term equivalent to the English word work and labor. This term is used to mean the same in this article.

Panahun is a term used by the Visayan to refer to time and weather. This term is used to mean the same in this paper.

Dapit is a term used by the Visayan to mean place and space and it is used as it is in this paper.

Himu is a Visayan term that is equivalent to the English term "make" which is used in this paper as it is.

Tuyo is a Visayan term that is equivalent to the English term "purpose or end."

Pinuy-anan is a Visayan term which denotes a place of abode or home.

\subsection{Results and Discussion}

\section{JPII's Philosophy of Work (Laborem Excercens)}

Laborem Excercens (LE) was written on the occasion of the 19th anniversary of Leo XIII's encyclical Rerum Novarum. The document (LE) was written during the time that John Paul II (JPII, 1981) describes as the "eve of new developments." JPII was very much concerned with the effects of these new developments on the human that he sees fit to remind the world of the fundamental nature of man and work. At the very beginning of the encyclical, he would emphasize that at the beginning of his pontificate, he made it clear that "humanity" is the point of reference of his pontificate, as he published the encyclical Redemptor Hominis. That is why in LE, the Pope, also crafted it from the anthropological doctrine of the Church that man is an Imago Dei. The encyclical is divided into five parts; Introduction, Work and Man, Conflict between Labor and Capital, Rights of Workers, and Elements for Spirituality of Work.

\section{Work and Man}

Work is fundamental to man as supported by the revealed word of God and the life sciences. It is the thing that sets humans apart from other animals because they alone can work (John Paul II 1981). In the book of Genesis, JPII argued that when God said, "Be fruitful and multiply, fill the earth and subdue it," God explicates the relationship between man and work. He claimed that though it has not been stated in words, yet it is clear that man is called to work.

"It is clear that the term "the earth" of which the biblical text speaks is to be understood in the first place as that fragment of the visible universe that man inhabits. By extension, however, it can be understood as the whole of the visible world insofar as it comes within the range of man's influence and of his striving to satisfy his needs. The expression "subdue the earth" has an immense range. It means all the resources that the earth (and indirectly the visible world) contains and which, through the conscious activity of man, can be discovered and used for his ends" (John Paul II, 1981: 6).

Man is called to subdue the earth and satisfy his needs. This is the basis of his dignity. For this 
reason, he said at the beginning of his encyclical, "through work man must earn his daily bread (John Paul II, 1981: 1)." Man is closely tied with work, and man is destined for work (John Paul II, 1981: 9). Work constitutes man's very nature because of all creatures; it is the only man capable of doing work (John Paul II, 1981: 1). He further claims, "Work is a good thing for a man-a good thing for his humanity-because through work man not only transforms nature, adapting it to his own needs, but he also achieves fulfillment as a human being and indeed, in a sense, becomes more a human being" (John Paul II, 1981: 15).

Work is even necessary for society and family as its basic unit. He said, "work is the condition that is needed to build a family for its sustenance (John Paul II, 1981: 14). He said further, "obviously, two aspects of work in a sense come into play here: the one making family life and its upkeep possible, and the other making possible the achievement of the purposes of the family, especially education. Nevertheless, these two aspects of work are linked to one another and are mutually complementary in various points (John Paul II, 1981: 14)." But what is work for the Pope?

Work means any human activity. Anything that a human person does is work. Whether eating, drinking, tilling, thinking, or inventing, these are all works (John Paul II, 1981: 6). With this premise, "anything that a human person does is work" means work cannot be separated from man. Work is always the inevitable consequence of being and becoming a man. That is why the Pope said, "man's life is built up every day from work, from work it derives its specific dignity" (John Paul II, 1981: 2). JPII has proposed two ways to look at work; objectively and subjectively.

First, objectively speaking, work finds expression in culture and civilization (John Paul II, 1981: 6). It might be through domesticating animals or extracting resources from the earth and seas to satisfy his needs. That is why any activity in agriculture or the industry is considered work. Furthermore, objectively, work could either be manual or intellectual (John Paul II, 1981: 1). Farming, domesticating animals, construction work are examples of manual labor, while intellectual work finds expression in heading a group, formulating theories, and the like. These two kinds of work are interrelated and complementary with each other. An engineer who plans the construction of a building is an example of intellectual creation, while the work of a construction worker who manually piles rocks according to the engineer's plan is manual. The two are important in their own accord because a building cannot stand without a plan and a person who puts it into action. This brings us to the second important aspect of work.

Secondly, in a subjective sense, man is the subject of work. And this corresponds to a deep ethical or moral question. Since man is the very subject of work, work begins in man. Therefore, man becomes the primary basis of the value of work, and the dignity of work must be sought on the subjective dimension rather than on the objective one (John Paul II, 1981: 9). If we bring back the kinds of work mentioned above, manual and intellectual labor must be held with the same dignity and value primarily because of the subject. An engineer's job has the same satisfaction and value as a laborer who tries to build in his hands the building. It is in the same case with a doctor and a medical technologist who collaborate to diagnose a patient. An employer cannot just say, "There is no hospital without doctors" while neglecting the other practitioners' work's vital aspect. This comment is merely ignorant of the fundamental subjective value of work that is equal. In this case, whenever there is a conflict of work interests, the worker's well-being must be prioritized. Therefore, before the objective value of work is graded and labeled, it is necessary to note that all works are valuable because of the subject. 
Given this way of understanding things, and presupposing that different sorts of work that people do can have greater or lesser objective value, let us try nevertheless to show that each variety is judged above all by the measure of the dignity of the subject of work, that is to say, the person, the individual who carries it out. On the other hand: independently of the work that every man does, and presupposing that this work constitutes a purpose-at times a very demanding one-of his activity, this purpose does not possess a definitive meaning in itself. In fact, in the final analysis, it is always the man who is the purpose of the work, whatever work it is done by man-even if the standard scale of values rates it as the merest "service" the most monotonous even the most alienating work (John Paul II, 1981: 9).

It is always necessary to bear in mind that work begins and ends in man. Work is there for a man while at the same time man is the one that does the working. The value of work may differ objectively, but this difference must not be applied subjectively. Such as the value and dignity of a person does not depend on the title, he/she earns.

\section{Labor and Capital Conflict}

JPII points out that labor and capital conflict immerged as a consequence of industrial development which is interpreted by some as a socioeconomic class conflict that is expressed in the ideological conflict between liberalism and communism/socialism (John Paul II, 1981:11). As perceived by the pope, the root of the conflict stems from the opposition of labor and capital which he called the error of economism which is a product of the error of materialism which claims the superiority of material aspects over spiritual and personal aspects. Labor cannot be separated from the capital and placed in opposition to it. To solve this conflict, it must be considered that they are intermingled and interdependent. However, even if labor and capital are intermingled, it must be clear that labor claims priority over capital. In a sense, JPII is claiming that their interdependence does not mean equality. Labor is still over the capital. In this way, it would be easy to avoid moral problems such as the commodification of work expressed in the "merchandise" perspective of work and the giving greater importance of the object (outcome) than the subject (worker) and move for better treatment of labor such as "work ownership" expressed in percentage sharing of profit.

\section{Moral Dimension of Labor}

JPII favors a personalist approach to labor. This is evident not just in his economic equation of labor over capital but also in his claim that labor is a human right. JPII argues that work is a human right because it is also connatural with the man just like any other human rights proclaimed by international organizations (John Paul II, 1981: 16). With this claim, it is inferential that the primary right of workers is the right to work. Any treatise of a worker's right is nothing if it does not include the right of the people to work. For this reason, JPIl further argues that it is the obligation of both the worker and the employer (direct or indirect) to create a humane working environment. The pope recognizes the need for employers to form unions that will help promote their interests as workers, the direct employers to religiously implement labor laws and contracts, the indirect employers, especially the state, to establish ethically acceptable labor policies that are beneficial for the workers, like just remunerations, and create jobs to accommodate the rights of workers to work according to their abilities and inabilities. 


\section{Spiritual Dimension of Labor}

JPII devotes the last part of his encyclical to the discussion on the Spirituality of work. First, he argues that work is sharing the work of the creator. Being an imago Dei, man shares the work of the creator according to his limits even in the most ordinary human activity. Second, JPII argues that man does not just participate in the work of the creator but also human work was elated by God through Jesus Christ doing human work himself and thus giving importance to human activity. Lastly, JPII argues that Christian work spirituality is also human participation to the redeeming work of God through his suffering, death, and resurrection has redeemed the world.

\section{The need for a Visayan Philosophy of Labor}

JPII claims that work is fundamental and inseparable from man. It is essential for society and family. That is why it is rooted in one's culture and civilization. Because of this perceived nature of work, he arrived at his conclusion, which is his most important contribution to the discussion of work, the idea that "man is the subject of work" and as a consequence labor must be prioritized over the capital. But, why is there a need for a Visayan philosophy of labor?

First, JPII's claim that work is fundamental to man is deduced from the biblical standpoint. While there is nothing wrong with this method, it is bound to its limitations. The bible is a holy book for Christians. It might be wrong to claim that the bible is respected only by the Christians because there are non-believers of Christ who might respect the teachings of Christ. To insist on perceiving everything from the bible connotes exclusivism which the life and works of JPII certainly deny. While it is true that the majority of Filipinos are Christians, it must be noted that they are Filipinos before they become Christians. To explain work from the Christian perspective is at most only a half of it. Therefore, there is a need for a Visayan understanding of Labor. Second, the need for a Visayan philosophy of labor is supported by JPII's claim that labor is rooted in one's culture and civilization. If labor is rooted in culture and civilization, then culture and civilization have so much to say about labor.

Since the need for a Visayan philosophy of labor is established from the claims of JPII. The question is how can people come up with a Visayan philosophy of labor? So, the authors propose that one way is to look at it from the notion of kahimtang.

\section{The Visayan Notion of Kahimtang}

The word kahimtang is used in several Filipino languages such as Cebuano, Samar - Leyte (Waraywaray), and Hiligaynon. These languages are used in the Visayas and Mindanao areas. The word generally has a similar connotation among these languages but it best serves this article to limit and focus and on the Cebuano understanding of the word to avoid further nuances of the term which is not covered in this article. The Cebuano word kahimtang is used to describe one's state of being. The authors claim that a deeper understanding of the word kahimtang leads to a further understanding of Filipino consciousness.

In "A Dictionary of Cebuano Visayan" by Wolff (1972), kahimtang is noted to be a derivation from the root word butang. Butang could be a verb or a noun. When used as a noun it means a thing or situation. When used as a verb which means to put down in or on. Wolff traced this word kahimtang to be a combination of affix ka (short for pagka though it must be noted that there are several connotations for the affix), another affix pahin (used in the word pahimutang), and butang (the root word). The Visayan word kahimtang means the way things are or situation, according to the dictionary. However, as a Cebuano Visayan, it 
would be easier and deeper to understand the word kahimtang as a combination of three words ka (short for ikaw or 'you' in the English language), himu (to make) and butang (thing, situation or state). Using this perspective, it is safe to say that kahimtang is personal, something an individual makes, and a state of a person.

Kahimtang is personal. The word $k a$ is a secondperson singular noun, short for Ikaw. But what does it mean to say that kahimtang is personal? It means kahimtang is intricately connected to a particular human person and it is highly unlikely that there are the same kahimtang for every person. Although the term kahimtang is used with a social context like in the phrase, 'mao ni ang kahimtang sa katilingban' it must be noted that a society is a composition of several individuals who have some commonalities. And is only possible to speak of kahimtang sa katilingban because of the individuals who are consciously in a kahimtang. The ka (human person) is supposed to be the base and foundation of kahimtang.

In addition, kahimtang is something the individuals make (himu). It is this understanding of kahimtang where the work or labor plays a significant role. To make something is to work for something. However, it must be clear that for the Visayan, not everything about kahimtang is a direct consequence or fruit of one's work. Kahimtang is also perceived by the Visayan as something Godgiven (Acampado \& Fernandez, 2019). They claim that there are a lot of things in one's life that is unmerited. These things are usually the basics of life, like family, place, time, etc. These things are mostly a priori and without which one cannot speak of being and becoming of a human person. Therefore, the term himu could mean subjectively or objectively. Subjectively, it is the human person that makes her kahimtang while objectively, God has made our kahimtang. Both could be understood dialectically and/or complementarily.
The third point is kahimtang is a state or more precisely a state of being for a human person. It means that kahimtang is the entirety of a human person considered. It is the actuality and the potentiality of the person combined. Beyond superficiality, kahimtang is more than a situation but encompasses it. Not just mere conditions but also actual experiences of these conditions that make a person.

\section{The Visayan Philosophy of Labor}

Reflecting from the notion of kahimtang, Acampado (2021) was able to conclude that Visayan people are generally compatibilist because they claim that no person escapes the a priori conditions which are the God-givens in life, such as family, sex, social status, financial status, space, and time. But all of the givens are not constant and this is where work plays a very significant role for the Visayan. Labor, then, is essentially the expression of freedom for the Visayan. If conflict theory claims that the clash of classes is the dynamo of society leading to a classless society, the notion of kahimtang, leads us to the conclusion that labor is the dynamo of kahimtang. Labor or work is the driving force to a better or worse kahimtang.

Work is translated in Cebuano as buhat which is used interchangeably with the word himu. To illustrate, kadaghan sa buluhaton can also be stated as kadaghan sa himuun. In the Cebuano Dictionary by Wolff (1972), there is a difference between the two. Buhat is referred to as 'do' and himu as 'make' in the English language. If the distinction between 'do' and 'make' is applied, then it follows that buhat refers to something general and abstract while 'himu' refers to something specific and physical. However, this distinction is not always true since in Cebuano these words are used interchangeably like this example taken from the old dictionary by De La Encarnacion (1883), "Dili acó mahímo niána, cay máy acó ug bóhat nga lain, cay máy 
bóhat cóng láen (I cannot do that because I am doing something). For clarity's sake, it is deemed necessary to maintain the English distinction of buhat and himu although work can be translated between either of the two. But using the notion of kahimtang, the kind of work needed is himu.

Using the Visayan compatibilism mentioned above, it is safe to define himu as an act of using the given conditions, especially time (panahun) and space (dapit), for the betterment of his/her kahimtang. Three elements in the definition must be expounded. First, himu is an act. Second, himu is making use of God-given conditions (space and time). Lastly, himu is geared towards the betterment of one's kahimtang.

\section{Himu is an Act}

An act is essentially doing something or something that has been done. Both words himu and buhat may be used to translate the word 'act'. But the most important question is what kind of act? It was explained before that himu is a word that composes kahimtang. So, it must be something specific and physical.

In general ethics, Glenn (1968) differentiates act into the human act and the act of man. Human act means a product of deliberation and consciousness, while man's act is a product of unconscious action. While the human act is within the bounds of morality, the act of man is not. Himu requires a special kind of understanding that is similar to that of the human act. It is not himu when something is done in the absence of purpose or consciousness. A person who is acting might be doing something, but in the absence of purpose and consciousness, it cannot be classified as himu. Purpose and consciousness are two concepts essential in the idea of himu. The purpose is also understood as an intention or the end of the agent and translated in Cebuano as tuyo. Furthermore, another necessary idea of himu is utility. Usefulness is understood by the Visayan as gamit. Anything did that is not useful is compared and equated to nothing. A person lying on the bed all day (except for those with a disability) has done something. But since the action is useless to some extent, then it is equivalent to doing nothing. For this reason, no mother is happy when she finds out that her child has spent the day lying on the bed and say, wa kay nahimu (you have done nothing).

\section{Himu is Making Use of Conditions}

It was established before that kahimtang is God-given. It means God is the giver of one's kahimtang. But then again, it must not be said that Visayan people do not subscribe to freedom. Human beings have to work for the kind of kahimtang they think best by making use of the given conditions such as time (panahun) and space (dapit). Panahun (time) and dapit (space) are necessary conditions that influence kahimtang. Acampado and Fernandez (2019) claimed that within the context of kahimtang the Visayan idea of space is geographical. They understood space as both pinuy-anan (home) and himuan (workplace). Dapit nga himuan is a vital concept for the Visayan. It is because himu plays an essential part of kahimtang and the human person and dapit nga himuan affects kahimtang. To illustrate it, in establishing a business, a person will consider the place (dapit) to develop a business. A good location is a condition for a good profit. Dapit can either be subjectively good or bad, depending on the situation. Simply said, a person's kahimtang is positively influenced by a good dapit and negatively impacted by a lousy dapit. However, it is good to emphasize that the goodness or badness of a dapit has a subjective aspect.

Time, as the other condition of kahimtang, is understood by the Visayan objectively and subjectively. Objectively, panahun is dynamic, continually changing, and inevitable. With this 
characteristic of the time, it is almost understood as the cause of change. Whenever time finds its way to man, there is always corresponding change that transpires. While subjectively, time is controllable. It is evident in all aspects of human activity. Time is and has to be appropriated to make the most of one's time. That is why a person lying in bed all day has not claimed his/her time wisely, and his actions are useless. Time can also be favorable (maayo nga panahun) and unfavorable (dili maayo nga panahun) to a person. A fair time brings luck and blessing, while an unfortunate time brings discomfort or bad luck. However, in whatever condition, such as maayo or di maayo nga panahun and dapit, a person has to make the most of these conditions. Man has less or without a choice but to make use of these conditions, especially with time. Being so dynamic, time can pass at an instant without a person realizing it. Because of this character of time, man cannot and should not spend it idly only to find out that he/she loses several opportunities.

Work is the expression of human freedom in the persistent human condition affected by space and time. It is a man's way of struggling to make his/her kahimtang better. When a person is born, everything is determined. As man gains consciousness of their kahimtang immediately the struggle begins but more so when a person acquires a greater understanding of his/her kahimtang. Life is a constant struggle with his present kahimtang. This struggle is observable in whatever kind of workman does to alleviate his/ her kahimtang.

\section{Himu is Geared towards Betterment of Kahimtang}

Finally, work is the only tool of man to change one's kahimtang. If Sartre (1973) claims that man is condemned to be free, this condemnation must be the freedom expressed in work and the only tool for a better kahimtang. In this case, man is condemned to work. Man is, after all, condemned to struggle for a better kahimtang. The claim that man is convicted to work is not necessarily a negative perspective of work as some might think. It is instead a glorification of labor. Using this perspective, the human being has been married to work like an indissoluble character printed in the inner core of man. With this, a person who does not work is questionable. This statement is not just a simple conclusion from the argument made but an observation of the human experience. That is why in serious mating, one of the essential questions considered is, does he/she work? Does he/she have work? This question is not just mere discrimination to those who do not work but an affirmation of the reality of human existence that man is condemned to work. There is a saying which says, "Work to live do not live to work." This proposition is meaningless because we exist to work. It is part of being condemned to work. It is not a claim, though, that man has to work without rest but let the rest be part of the work, a purposeful and conscious act. Resting does not contradict the idea of work as a condemnation of man if it points towards the betterment of kahimtang.

Work can be harmful or useful. Since any act made purposefully may be classified as good or bad, how do people identify it? In the context of kahimtang, there is only one criterion for a good act, and that is anything that leads to its betterment. When work leads to a better kahimtang, then it is good. However, if it leads to the degradation of kahimtang, it is not good. Man is always in the pursuit of a better kahimtang. He/she spends all the resources like time and space to have a better kahimtang. However, it is important to note that the pursuit of a better kahimtang is potentially infinite. It is not easily satisfying, but man is the limit. As Protagoras would say, "man is the measure of things," man becomes the measure of the best kahimtang. As long as his/her desire for a better kahimtang is not satisfied, there is yet the best. Man is condemned to work for this purpose. 
Comparative analysis of Visayan and JPII's Philosophy of Labor

So far, the article has been able to explain the Visayan philosophy of labor within the context of kahimtang. Further, there was a discussion on the philosophy of John Paul II on labor. Now the researchers will treat some points of comparison from these two philosophies.

First, both have an element of the divine. The Visayan philosophy of labor is seen as a consequence of freedom, which is an essential aspect of kahimtang. Kahimtang, on the other hand, is something God-given. Therefore, labor for the Visayan has a divine element. It is part of the totality of kahimtang that is bestowed by God to man. If a man works, that is because God designed it so.

Second, both understand work as anything a man does consciously. In JPII's idea, work is something that separates man from the rest of the animals. It is a way of recognizing the conscious aspect of work. In the Visayan philosophy, consciousness is critical to qualify as work.

Third, both philosophies understood labor as something fundamental. In the Visayan idea, labor is fundamentally necessary for the betterment of kahimtang, while in John Paul Il's philosophy, labor is a fundamental necessity as an imago Dei and a fundamental right it is a human right.

\section{An enriched Visayan perspective of labor}

Inferring from the analysis above, the researchers found points from JPII's Philosophy that will enrich the Visayan perspective of labor.

First is the personalist view as applied to kahimtang. It is argued above that work is an expression of freedom to change one's kahimtang. Therefore, a man works to pursue a better kahimtang, the aim is always man himself. It is important then to understand well the concept better kahimtang to avoid erroneous pursuit.
The idea of John Paul II on the subject-object distinction and personalist argument can help to clear out this aspect. The subject over object emphasized by John Paul II is given significant bearing and application. The subject is prioritized over the object. If this statement is applied to the Visayan idea of kahimtang and man, man becomes the subject, and kahimtang becomes the object. It means that man is more important than kahimtang per se. After all, kahimtang cannot find relevance without the man. That is why any work that attempts to make kahimtang better must take priority man himself. A better kahimtang, then, is something that respects human dignity. A better kahimtang is always pursued to become a better man. With this saying, having a better kahimtang must respect the dignity of man, which is in the individual human person. Every pursuit of a better kahimtang must always consider human dignity, and if work as a tool to change one's kahimtang agrees with human dignity. Man must not afford to lose one's dignity because of work. Neither, other people's dignity is transgressed because of your work.

Second is the reflection from JPII's moral dimension of labor. While it is argued that labor is fundamental for man's kahimtang, it does not mean that the Visayan has a clear idea that labor is a human right. This perspective can be used to enliven the notion of the Visayan idea of labor. It is possible to argue that because labor is a fundamental human right, it is also a human right to desire and work for the betterment of kahimtang. Furthermore, since it is a human right, the direct and indirect employer (state) has the obligation to create conditions that would facilitate this process. Since it is the individual who identifies the best possible kahimtang, the state must always consider human autonomy. It means man is the agent who identifies the best kahimtang for him and must pursue that best kahimtang according 
to the principle of autonomy. The emphasis of JPII against the old capitalism and communism, which do not uphold human dignity especially that of the workers, must also be recognized. And perhaps the employer (direct or indirect) can also work on capitalism that does not exploit human persons or cummunism that does not lead to violence. In the Visayan understanding of labor as a tool towards a better kahimtang, a capitalistic way of doing business that marginalizes and exploits must be controlled by the government who has the power to do so. The ordinary people trying to make sense of their kahimtang are prone to this exploitation and marginalization. That is why they must be given significant attention and priority.

Lastly, the Visayan philosophy of Labor can also be enriched using the Christian perspective most especially that the Visayas is also dominated by Christians who just celebrated the 500th anniversary of the coming of the Catholic faith. The Visayan idea of a Divine giver of kahimtang can be given a Christian perspective. It can be argued that at the end, the best possible kahimtang that a Visayan can aspire and work is always a kahimtang with God.

\subsection{Conclusion}

Visayan philosophy has yet a long way to go. There is even no unanimous consensus yet if there is Filipino philosophy. This struggle is part of its development. This philosophical interpretation of kahimtang, where the Visayan philosophy of labor is extracted, attempts to think in-depth about their experiences. For this reason, a conclusion is made. First, ka-him-tang is understood as a combination of three words ka (ikaw), Himu, and butang. Second, kahimtang is essentially intertwined with human life. It is the condition that everyone has in his life. Furthermore, it is understood as a Godgiven state of being-human. This understanding is full of meaning, one of which leads to the base of the Visayan philosophy of labor, that is, their compatibilist understanding of kahimtang. They believed that kahimtang is a combination of both a priori (mostly unchangeable conditions) and posteriori (mostly mutable conditions). Third, it is argued that kahimtang is changed through the principle of work. Work is understood as the expression of freedom to alter their kahimtang. Whenever a person wants and desires to change his/her kahimtang, he must express it through work. Or simply, he must work for it. Fourth, that life's end is the best possible kahimtang. Everyone is naturally inclined to this goal because this is an innate tendency of man. That is why John Paul II's philosophy gave us an idea of how important to look at labor with a bias for the subject (man) because he is the beginning and end of work. Fourth, as John Paul would claim that labor must be over the capital, so capital must be on the service of a human person's quest for the best kahimtang. It leads to the fifth, and the last idea presented, that favorable working conditions must be made to encourage and help those who pursue the best possible kahimtang that everyone desires.

\section{References}

Acaali, C. (1997). A study of John Paul II's theology of work in "Laborem Exercens" with special reference to Julius Nyerere's philosophy of work. [Doctoral dissertation, Duquesne University]. PhilPapers. https://philpapers.org/rec/ ACAASO

Acampado, A. G. (2021). A philosophical analysis of compatibilism from the indigenous notion of kahimtang. International Journal of Humanity Studies, 5, (1), 1-13. https://e-journal.usd. ac.id/index.php/IJHS/article/view/3423

Acampado, A. G., \& Fernandez Jr, G. C. (2019). 
Philosophical understanding of space from the Visayan notion of Kahimtang. Asia Pacific Journal of Multidisciplinary Research, 7(1), 42-51. http://www.apjmr.com/wp-content/ uploads/2019/01/APJMR-2019.7.1.2.05.pdf

Baum, G. (1982). The Priority of Labor: A Commentary on Laborem Exercens: Encyclical Letter of Pope John Paul II. Ramsey. Paulist Press.

Clark, M. (2007). Integrating human rights: participation in John Paul II, Catholic social thought and Amartya Sen. Political Theology, 8 (3), 299-317. https://doi.org/10.1558/poth. v8i3.299

De La Encarnacion, J. F. (1883). Diccionario bisaya-español. Tip. de" Amigos del país,". https://archive.org/details/ aqp5055.0001.001.umich.edu/page/n1/ mode/2up?q=bisaya+espanol

Demetrio, F. P. A. (2014). Assessing the Developmental Potentials of Some Twelve Discourses of Filipino Philosophy. Philippiniana Sacra, 69(147), 189-230. https:// www.academia.edu/12035138/Assessing_ the_Developmental_Potentials_of_Some_ Twelve_Discourses_of_Filipino_Philosophy

Fernandez, G. \& Villaluz G. (2017). Teaching Indigenous Peace Concepts from Visayan Fisherfolks and Farmers through the Course Philosophy of the Human Person. Recoletos Multidisciplinary Research Journal, 5(1), 32-49. https://doi.org/10.32871/rmrj1705.01.04

Glenn, P. (1968). Ethics. B. Herder Book Co.

Gripaldo, R. (2007). Filipino philosophy, western tradition, and nation building. Philosophia:
International Journal of Philosophy (Philippine e-journal), 36(1), 40-52. https://c4fb26e2a44c-4aea-96c2-74fd10a43d0e.filesusr.com/ ugd/dcdc59_3e573c4977cb4e94b2e64cbf1c e0b542.pdf

Herbert, J. (2013). Be Still and See: Leisure, Labor, and Human Dignity in Josef Pieper and Blessed John Paul II. Logos: A Journal of Catholic Thought and Culture, 16 (2): 144-159. https://www.academia.edu/15151246/Be_ Still_and_See_Leisure_Labor_and_Human_ Dignity_in_Josef_Pieper_and_Blessed_ John_Paul_II

John Paul II (1981). Laborem exercens. John Paul II encyclicals. https://www.vatican.va/content/ john-paul-ii/en/encyclicals/documents/hf jp-ii_enc_14091981_laborem-exercens.html

Matheny, K. (2014). The disappearance of labor unions and the social encyclicals of Popes John Paul II and Benedict XVI. S. Cal. Interdisc. LJ 23, 1. https://gould.usc.edu/why/students/ orgs/ilj/assets/docs/6\%20-\%20Matheny.pdf

Mercado, L. (1974). Elements of Filipino philosophy. Divine Word University Publications.

Mercado, L. (2016). Reflections on the status of Filipino philosophy. Kriteke, 10 (2), 21-28. https://www.kritike.org/journal/issue_19/ mercado_december2016.pdf

Ocay, J. (2015). Philosophy at the Margins: Exploring the Philosophy of Work of the Elderly People in some Remote Areas of Negros Oriental. Social Ethics Society Journal of Applied Philosophy, 1(1), 1-18. http://ses-journal.com/ wp-content/uploads/2017/09/Philosophyat-the-Margins-Exploring-the-Philosophy- 
of-Work-of-the-Elderly-People-in-someRemote-Areas-of-Negros-Oriental.pdf

Pada, R. T. (2014). The Methodological Problems of Filipino Philosophy. Kritike: An Online Journal of Philosophy, 8(1), 24-44. http://www.kritike. org/journal/issue_14/pada_june2014.pdf

Russo, J. \& Corbin, B. (1999). Work, organized labor, and the Catholic Church: boundaries and opportunities for community/labor coalitions. Wayne State University Press.

Sarte, J. P. (1973). Existentialism and Humanism. transl. Philip Mairet, Methuen. Methuen \& Co. Ltd.

Velez, A. (2018). The Silence of Nayanaya in Cebuano Songs. Budhi, 22(1), 24-42. https:// ajol.ateneo.edu/budhi/articles/147/1681

Wisman, J. (1998). Christianity, John Paul II and the future of work. International Journal of Social Economics, 25 (11/12), 16581671. https://www.researchgate.net/ publication/235294490_Christianity_John_ Paul_II_and_the_future_of_work

Wolff, J. (1972). A dictionary of Cebuano Visayan. Cornell University, Southeast Asia Program and Linguistic Society of the Philippines. https://ecommons.cornell.edu/ handle/1813/11777 